\title{
FAKTOR-FAKTOR YANG MEMPENGARUHI NILAI PERUSAHAAN: KEBIJAKAN DIVIDEN SEBAGAI PEMEDIASI
}

\author{
AULIA NUR HASANAH \\ WIDYAWATI LEKOK \\ Trisakti School of Management, Jl. Kyai Tapa No. 20, Jakarta 11440, Indonesia \\ widyaron@yahoo.com
}

\begin{abstract}
The purpose of this study is to get emperical evidence about the influence of managerial ownership, financial leverage, profitability, firm size, investment opportunity, dividend policy, cash holdings, and number of independence board to the firm value; The influence of managerial ownership, financial leverage, profitability, firm size, and investment opportuinity to the firm value which is mediated by dividend policy. The population are non financial companies listed in Indonesia Stock Exchange (IDX) from the period of 2014 to 2016 . This study used 55 samples and samples selection procedure used purposive sampling. Data were analyzed using multiple regression method and path analysis. The result of this study shows that financial leverage, profitability, and dividend policy have influence toward firm value. While managerial ownership, firm size, investment opportunity, cash holdings and independence board have no influence toward firm value. Dividend policy mediate the correlation of managerial ownership and firm size to the firm value. While dividend policy does not mediate financial leverage, profitability, and investment opportunity to the firm value.
\end{abstract}

Keywords: Firm value, managerial ownership, financial leverage, investment opportunity, dividend policy

Abstrak: Tujuan penelitian adalah untuk mendapatkan bukti empiris tentang pengaruh kepemilikan manajerial, leverage keuangan, profitabilitas, ukuran perusahaan, peluang investasi, kebijakan dividen, kepemilikan kas, dan jumlah dewan independensi terhadap nilai perusahaan; Pengaruh kepemilikan manajerial, leverage keuangan, profitabilitas, ukuran perusahaan, dan peluang investasi terhadap nilai perusahaan yang dimediasi oleh kebijakan dividen. Populasi adalah perusahaan non keuangan yang terdaftar di Bursa Efek Indonesia (BEI) dari periode 2014 hingga 2016. Penelitian ini menggunakan 55 sampel dan prosedur pemilihan sampel menggunakan purposive sampling. Data dianalisis menggunakan metode regresi berganda dan analisis jalur. Hasil penelitian ini menunjukkan bahwa leverage keuangan, profitabilitas, dan kebijakan dividen memiliki pengaruh terhadap nilai perusahaan. Sedangkan kepemilikan manajerial, ukuran perusahaan, peluang investasi, kepemilikan tunai dan dewan independensi tidak memiliki pengaruh terhadap nilai perusahaan. Kebijakan dividen memediasi korelasi kepemilikan manajerial dan ukuran perusahaan dengan nilai perusahaan. Sementara kebijakan dividen tidak memediasi leverage keuangan, profitabilitas, dan peluang investasi ke nilai perusahaan.

Kata kunci: $\quad$ Nilai perusahaan, kepemilikan manajerial, leverage keuangan, kesempatan investasi, kebijakan dividen 


\section{PENDAHULUAN}

Tujuan utama perusahaan yang terdaftar dalam bursa efek adalah menigkatkan kemakmuran pemegang saham. Nilai perusahaan yang tinggi menjadi keinginan pemilik perusahaan, sebab dengan nilai perusahaan yang tinggi menunjukkan kemakmuran pemegang saham juga tinggi. Secara harafiah nilai perusahaan diukur dari nilai pasar wajar dari harga saham. Bagi perusahaan yang sudah publik maka nilai pasar wajar perusahaan ditentukan mekanisme permintaan dan penawaran di bursa, yang tercermin dalam listing price (Suharli 2006).

$$
\text { Yudiana dan Yadnyana (2016) }
$$
memaparkan dengan adanya keterlibatan kepemilikan saham, manajer akan bertindak secara hati-hati karena mereka ikut menanggung konsekuensi atas keputusan yang diambilnya. Selain itu, manajer akan termotivasi untuk meningkatkan kinerjanya dalam mengelola perusahaan. Dengan meningkatnya kinerja manajer dalam mengelola perusahaan maka akan meningkatkan nilai perusahaan.

Financial leverage adalah salah satu rasio yang menggambarkan struktur modal perusahaan. Struktur modal yang optimal dianggap mampu memaksimalkan nilai perusahaan. Penggunaan utang memiliki dampak positif dan negatif. Dampak positif dari penggunaan utang adalah mengurangi konflik keagenan, karena dengan penggunaan utang akan mengurangi pembiayaan dari saham (Jensen \& Meckling 1976). Selain itu, adanya beban bunga yang bersifat tetap mengharuskan manajer untuk terus meningkatkan laba agar dapat memenuhi kewajiban bunga. Bunga yang menjadi pengurang pajak juga menjadi keuntungan bagi investor karena perusahaan akan mendapat laba per saham yang lebih tinggi. Namun disisi lain, bunga yang bersifat tetap dapat memicu kegagalan pembayaran kewajiban perusahaan.
Laba juga menunjukkan kemampuan perusahaan untuk bertumbuh. Jika perusahaan memiliki profit yang tinggi, maka para investor menilai bahwa prospek perusahaan itu baik dan akan membuat nilai perusahaan menjadi naik (Setyowati dan Nursiam 2014, 388). Harga saham perusahaan akan dipengaruhi oleh kinerja perusahaan yang tergambar dalam laporan keuangan salah satunya rasio profitabilitas. Kenaikan profitablitas akan mempengaruhi harga saham dan akan menaikkan nilai perusahaan (Rasyid 2015).

Hasnawati dan Sawir (2015) menyatakan bahwa ukuran perusahaan dapat menentukan tingkat kemudahan perusahaan dalam memperoleh dana dari pasar modal dan menentukan kekuatan tawar-menawar dalam kontrak keuangan. Perusahaan dengan ukuran perusahaan yang besar, umumnya dapat memilih pendanaan dari berbagai bentuk utang, termasuk penawaran spesial yang lebih menguntungkan daripada perusahaan kecil. Perusahaan besar dianggap mampu mengendalikan kondisi pasar dan bertahan dalam persaingan. Sehingga tingkat risiko investasi pada perusahaan besar lebih rendah dibanding tingkat risiko perusahaan kecil.

Investment Opportunity Set (IOS) adalah nilai sekarang dari pilihan perusahaan untuk membuat investasi di masa depan. Penelitian ini menggunakan CAPX/A sebagai indikator. Winarto (2015) mengatakan bahwa untuk mencapai tujuan perusahaan maka perusahaan sebagai investor perlu mengambil keputusan investasi yang menghasilkan net present value yang positif.

Dividen merupakan hak pemegang saham biasa untuk mendapat bagian dari laba perusahaan. Pembagian dividen saham biasa dilakukan setelah kewajiban terhadap pemegang saham preferen terpenuhi. Dalam praktik pembagian dividen, perusahaan juga perlu mempertimbangkan apakah laba bersih perusahaan akan dibagikan sebagai dividen, ataupun akan digunakan untuk tujuan 
pendanaan. Keputusan yang diambil perusahaan mengenai dividen ini disebut sebagai kebijakan dividen (Sumanti dan Mangantar 2015).

Cash holdings adalah sejumlah kas yang disimpan perusahaan untuk menjalankan aktivitas perusahaan. Cash holdings mengindikasikan tingkat kas yang ditahan pada suatu perusahaan. Cash holdings merupakan salah satu ukuran apakah kas pada perusahaan tersebut cukup atau tidak berlebihan. Hal ini menunjukkan pentingnya cash holding dalam operasional perusahaan. Apabila perusahaan mampu menggunakan kas secara efektif dan efisien, maka nilai perusahaan pun akan meningkat.

Salah satu bukti diterapkannya corporate governance adalah dengan dibentuknya dewan komisaris independen. Dewan komisaris independen adalah anggota dari dewan komisaris yang berasal dari luar perusahaan publik dan memiliki otoritas untuk perencanaan, pengarahan, dan pengawasan aktivitas perusahaan (Sukmono 2015). Pengawasan yang dilakukan oleh dewan komisaris independen adalah memberikan arahan dan monitoring terhadap pengelolaan manajer dan menjamin bahwa pengelolaan tersebut sudah sesuai dengan strategi perusahaan (Widyasari et al. 2015). Dengan begitu, keberadaan dewan komisaris independen diharapkan mampu memperbaiki kinerja perusahaan sehingga dapat meningkatkan nilai perusahaan.

Penelitian ini adalah pengembangan dari penelitian yang dilakukan Rizqia et al. (2013). Perbedaan penelitian ini dengan penelitian sebelumnya terletak pada sampel dan periode penelitian, dimana penelitian sebelumnya mengacu pada data perusahaan manufaktur yang terdaftar di Bursa Efek Indonesia periode 2006-2011, sedangkan penelitian ini menggunakan sampel dari perusahaan non keuangan yang terdaftar di Bursa Efek Indonesia dengan periode penelitian
2014-2016. Perbedaan lainnya terletak pada variabel yang digunakan. Penelitian ini mengembangkan variabel penelitian sebelumnya yaitu kepemilikan manajerial, financial leverage, profitabilitas, ukuran perusahaan, investment opportunity, dan kebijakan dividen dengan menambah variabel dua variabel baru yakni cash holdings dan dewan komisaris independen (Nisasmara dan Musdholifah 2016) yang mempengaruhi nilai perusahaan.

Tujuan penelitian ini adalah mengetahui (1) Pengaruh kepemilikan manajerial terhadap nilai perusahaan. (2) Pengaruh financial leverage terhadap nilai perusahaan.(3) Pengaruh profitabilitas terhadap nilai perusahaan. (4) Pengaruh ukuran perusahaan terhadap nilai perusahaan. (5) Pengaruh investment opportunity terhadap nilai perusahaan. (6) Pengaruh kebijakan dividen terhadap nilai perusahaan. (7) Pengaruh cash holdings terhadap nilai perusahaan. (8) Pengaruh dewan komisaris independen terhadap nilai perusahaan. (9) Pengaruh kepemilikan manajerial terhadap terhadap nilai perusahaan melalui kebijakan dividen. (10) Pengaruh financial leverage terhadap nilai perusahaan melalui kebijakan dividen. (11) Pengaruh profitabilitas terhadap nilai perusahaan melalui kebijakan dividen. (12) Pengaruh ukuran perusahaan terhadap nilai perusahaan melalui kebijakan dividen. (13) Pengaruh investment opportunity terhadap nilai perusahaan melalui kebijakan dividen.

\section{Teori Sinyal}

Teori sinyal menjelaskan bahwa manajer akan memberikan sinyal kepada investor melalui laporan keuangan untuk meyakinkan bahwa perusahaan mempunyai ekspektasi memberikan keuntungan di masa mendatang (Godfrey et al. 2010, 375). Sinyal digunakan karena pihak manajemen lebih mengetahui informasi dengan baik dan akurat dibandingkan pihak luar. Sinyal juga bisa 
digunakan manajemen untuk meminimalisir asimetri informasi antara manajemen dan investor.

\section{Teori Keagenan}

Jensen dan Meckling (1976) menjelaskan hubungan keagenan sebagai suatu kontrak dimana seseorang sebagai prinsipal melakukan perjanjian dengan pihak lain sebagai agen untuk menjalankan sebagian haknya yang termasuk otoritas pengambilan keputusan. Pemegang saham sebagai pihak prinsipal dalam mencapai tujuannya memilih manajer sebagai agen untuk menjalankan perusahaan. Idealnya agen yang dipilih oleh prinsipal dapat bertindak sesuai dengan keinginan dan tujuan pemegang saham. Namun terkadang manajer dan pemegang saham memiliki tujuan yang berbeda.

\section{Nilai Perusahaan}

Suroto (2015) mendefinisikan nilai perusahaan sebagai nilai pasar atau harga saham perusahaan di pasar. Nilai perusahaan yang tinggi juga menjadi keinginan para pemilik perusahaan, sebab dengan nilai yang tinggi menunjukkan bahwa kemakmuran pemegang saham juga tinggi (Hermuningsih 2013). Hal ini membuktikan bahwa meningkatkan nilai perusahaan telah menjadi tujuan jangka panjang perusahaan, terutama perusahaan yang terdaftar dalam bursa efek.

\section{Kepemilikan Manajerial dan Nilai Perusahaan} Muryati dan Suardikha (2014) dan Rizqia et al. (2013) menemukan bahwa kepemilikan manajerial memiliki pengaruh positif terhadap nilai perusahaan. Hal ini terjadi karena kepentingan manajer dengan pemegang saham eksternal dapat disatukan jika kepemilikan saham oleh manajer diperbesar sehingga manajer tidak akan memanipulasi laba untuk kepentingannya, dalam kepemilikan saham yang rendah, maka insentif terhadap kemungkinan terjadinya perilaku oportunistik manajer akan meningkat.

$\mathrm{H}_{1}$ Kepemilikan manajerial berpengaruh terhadap nilai perusahaan

\section{Financial Leverage dan Nilai Perusahaan}

Berdasarkan penelitian yang dilakukan oleh Winarto (2015) dan Rizqia et al. (2013) yang menyatakan bahwa varibael leverage memiliki pengaruh positif terhadap nilai perusahaan. Hal ini terjadi karena financial leverage dapat menjadi alat pengawasan untuk mengurangi masalah keagenan.

$\mathrm{H}_{2}$ Financial leverage berpengaruh terhadap nilai perusahaan

\section{Profitabilitas dan Nilai Perusahaan}

Beberapa penelitian terdahulu telah menguji secara empiris hubungan antara profitabilitas dan nilai perusahaan. Hasil penelitian Rizqia et al. (2013), Dewi dan Wirajaya (2013) dan Rasyid (2015) menyatakan profitabilitas berpengaruh positif terhadap nilai perusahaan. Pengaruh positif mengindikasikan pandangan yang menguntungkan investor apabila perusahaan mampu menghasilkan laba. $\mathrm{H}_{3}$ Profitabilitas berpengaruh terhadap nilai perusahaan

\section{Ukuran Perusahaan dan Nilai Perusahaan}

Hasil penelitian Rizqia et al. (2013) dan Prasetia et al. (2014) menyatakan bahwa ukuran perusahaan memiliki pengaruh yang positif terhadap nilai perusahaan. Hal tersebut terjadi karena semakin besar ukuran perusahaan maka perusahaan akan lebih baik dalam pengelolaan dan manajemen.

$\mathrm{H}_{4}$ Ukuran perrusahaan berpengaruh terhadap nilai perusahaan.

\section{Investment opportunity dan Nilai Perusahaan}

Beberapa penelitian mengungkapkan bahwa investment opportunity mempengaruhi nilai perusahaan, salah satunya penelitian 
Rizqia et al. (2013) dan Winarto (2015) yang menyatakan investment opportunity berpengaruh positif terhadap nilai perusahaan. Hasil ini membuktikan bahwa investment opportunity bisa menentukan reaksi pasar saham.

$\mathrm{H}_{5}$ Investment opportunity berpengaruh terhadap nilai perusahaan.

\section{Kebijakan Dividen dan Nilai Perusahaan}

Juhandi et al. (2013) menyimpulkan bahwa kebijakan dividen berpengaruh secara signifikan dengan arah positif terhadap nilai perusahaan. Hasil ini konsisten dengan penelitian Widodo (2016) dan Rizqia et al. (2013, 127). Pembagian dividen dianggap sebagai sinyal positif bahwa perusahaan memiliki prospek laba di masa depan sehingga dapat menaikan nilai perusahaan yang tercermin dari harga saham.

$\mathrm{H}_{6}$ Kebijakan dividen berpengaruh terhadap nilai perusahaan.

\section{Cash Holdings dan Nilai Perusahaan}

Ha dan Tai (2017) menyatakan bahwa cash holdings memiliki pengaruh positif dan signifikan terhadap nilai perusahaan. Perusahaan dengan tingkat cash holdings yang tinggi mencerminkan kemampuan perusahaan untuk mendapatkan kas dari aktivitas operasi dengan baik, selain itu perusahaan juga dinilai lebih baik dalam membayar segala kewajiban dan beban.

$\mathrm{H}_{7}$ Cash Holdings berpengaruh terhadap nilai perusahaan.

\section{Dewan Komisaris Independen dan Nilai Perusahaan}

Tata kelola yang baik menjadi salah satu kunci dalam meningkatkan nilai perusahaan. Salah satu bukti dilakukannya dewan komisaris independen adalah dengan membentuk dewan komisaris independen. Nisasmara dan Musdholifah (2016) dan Muryati dan Suardikha (2014) menyatakan dewan komisaris independen berpengaruh positif pada nilai perusahaan. Semakin banyak jumlah dewan komisaris independen menunjukkan semakin baik dewan komisaris yang melakukan fungsi pengawasan dan koordinasi dalam perusahaan.

$\mathrm{H}_{8}$ Dewan komisaris independen berpengaruh terhadap nilai perusahaan.

\section{Kepemilikan manajerial dan Nilai Perusahaan melalui Kebijakan Dividen}

Menurut penelitian Sumanti dan Mangantar (2015) dan Nuringsih (2005) menunjukkan bahwa variabel kepemilikan manajerial berpengaruh signifikan terhadap kebijakan dividen. Semakin besar kebijakan dividen maka nilai perusahaan juga akan meningkat.

$\mathrm{H}_{9}$ Kepemilikan manajerial berpengaruh terhadap nilai perusahaan melalui kebijakan dividen.

\section{Financial Leverage dan Nilai Perusahaan melalui Kebijakan Dividen}

Hasil penelitian Yudiana dan Yadnyana (2016, 134) menyatakan bahwa financial leverage memiliki pengaruh negatif terhadap kebijakan dividen. Semakin tinggi financial leverage maka akan semakin besar dana yang disediakan untuk melunasi utang sehingga akan mengurangi jumlah dividen yang akan dibayarkan. Hal tersebut tentu akan berdampak pada nilai perusahaan.

$\mathrm{H}_{10}$ Financial Leverage berpengaruh terhadap nilai perusahaan melalui kebijakan dividen.

\section{Profitabilitas dan Nilai Perusahaan melalui Kebijakan Dividen}

Yudiana dan Yadnyana (2016) yang secara parsial menunjukkan bahwa profitabilitas berpengaruh positif pada kebijakan dividen. Ini berarti semakin tinggi profitabilitas yang dimiliki suatu perusahaan maka akan semakin tinggi pula kemampuan perusahaan membayarkan dividen. 
$\mathrm{H}_{11}$ Profitabilitas berpengaruh terhadap nilai perusahaan melalui kebijakan dividen.

\section{Ukuran Perusahaan dan Nilai Perusahaan melalui Kebijakan Dividen}

Nuringsih (2005) dan Amah (2012) berpendapat bahwa ukuran perusahaan memiliki pengaruh positif terhadap kebijakan dividen perusahaan. Perusahaan besar akan cenderung membagikan dividen yang tinggi untuk menjaga reputasi di kalangan investor sehingga nilai perusahaan juga akan cenderung meningkat.

$\mathrm{H}_{12}$ Ukuran perusahaan berpengaruh terhadap nilai perusahaan melalui kebijakan dividen.

\section{Investment Opportunity dan Nilai Perusahaan melalui Kebijakan Dividen}

Mawarni dan Ratnadi (2014) dan Amah (2012) menyimpulkan investment oppoortunity berpengaruh negatif pada kebijakan dividen.
Semakin tinggi kesempatan investasi yang terbuka, maka perusahaan akan cenderung memilih investasi dan tidak membayarkan dividen kepada para pemegang saham. Hal tersebut tentu akan berdampak pada nilai perusahaan.

$\mathrm{H}_{13}$ Investment Opportunity berpengaruh terhadap nilai perusahaan melalui kebijakan dividen.

\section{METODA}

Penelitian kausalitas digunakan untuk menjelaskan hubungan sebab akibat antara variabel independen terhadap variable dependen dalam suatu penelitian (Sekaran dan Bougie 2016). Obyek dari penelitian ini adalah perusahaan non keuangan yang terdaftar di Bursa Efek Indonesia (BEI). Metode pemilihan sampel yang digunakan adalah metode purposive sampling.

Tabel 1 Prosedur Pemilihan Sampel

$\left.\begin{array}{llcc}\hline \text { No. } & \multicolumn{1}{c}{\text { Keterangan }} & \begin{array}{c}\text { Total } \\ \text { Perusahaan }\end{array} & \begin{array}{c}\text { Total } \\ \text { Data }\end{array} \\ \hline \text { 1. } & \begin{array}{l}\text { Perusahaan non keuangan yang terdaftar di Bursa Efek } \\ \text { Indonesia selama periode 2012 sampai 2016 }\end{array} & 376 & 1128 \\ \text { 2. } \quad \begin{array}{l}\text { Perusahaan non keuangan yang tidak menerbitkan } \\ \text { laporan keuangan menggunakan satuan mata uang } \\ \text { rupiah selama periode 2012 sampai 2016 }\end{array} & (84) & (252) \\ \text { 3. } \quad \begin{array}{l}\text { Perusahaan non keuangan yang tidak menerbitkan } \\ \text { laporan keuangan yang berakhir 31 Desember selama } \\ \text { periode 2012 sampai 2016 }\end{array} & (4) & (12) \\ \begin{array}{l}\text { Perusahaan non keuangan yang tidak memiliki } \\ \text { kepemilikan manajerial selama periode 2013 - 2015 }\end{array} & (159) & (477) \\ \text { 5erusahaan non keuangan yang tidak membagikan } \\ \quad \begin{array}{l}\text { dividen berturut-turut selama periode 2014-2016 } \\ \text { Total perusahaan yang digunakan sebagai sampel dalam } \\ \text { penelitian }\end{array}\end{array}\right)$

Sumber data yang digunakan dalam penelitian ini ialah data sekunder berupa laporan keuangan perusahaan non keuangan yang terdaftar di Bursa Efek Indonesia (BEI) selama tahun 2012 sampai dengan 2016, Perbedaan periode pengumpulan data dengan periode penelitian disebabkan karena pada penelitian ini data diambil dengan time lag 1 tahun dimana 
data kepemilikan manajerial, financial leverage, profitabilitas, ukuran perusahaan, investment opportunity, cash holdings, dan dewan komisaris independen pada tahun 2013-2015, sedangkan data kebijakan dividen dan nilai perusahaan diambil dari data tahun 2014-2016.

Nilai perusahaan merupakan indikator bagaimana pasar menilai perusahaan secara keseluruhan. (Fanani \& Yan 2016). Nilai perusahaan memiliki skala rasio dengan proksi pengukuran nilai perusahaan adalah Tobin's $Q$ yaitu nilai pasar ekuitas ditambah nilai buku kewajiban lalu dibagi nilai buku aset (Benson dan Davidson 2009).

Pengukuran kepemilikan manajerial menggunakan skala rasio yang membagi jumlah saham yang dimiliki manajemen dan direktur terhadap total saham beredar (Rizqia et al. 2013). Hutang digunakan perusahaan untuk meningkatkan aset, sehingga Financial Leverage dapat diukur dengan skala rasio yang menggunakan debt to to asset ratio (Rizqia et al. 2013). Profitabilitas adalah suatu rasio yang menggambarkan kemampuan perusahaan untuk menghasilkan laba pada suatu periode (Weygandt et. al. 2013). Variabel profitabilitas menggunakan rasio sebagai skala pengukuran. Rasio yang digunakan untuk mengukur profitabilitas adalah dengan menggunakan return on asset ratio yang membagi laba setelah pajak dengan total aset (Rizqia et al. 2013).

Ukuran perusahaan merupakan indikasi dari seberapa besar perusahaan dilihat dari besarnya aset yang dimiliki (Winarto 2015).
Dalam penelitian ini ukuran perusahaan diukur dengan menggunakan logaritma natural dari total aset dengan pengukuran skala rasio. Adapun formula yang digunakan adalah sebagai berikut (Rizqia et al. 2013). Investment opportunity dapat diukur dengan skala rasio yang menggunakan capital expenditure adalah pertumbuhan aset tetap dibagi dengan total aset (Arieska dan Gunawan 2011):

Kebijakan dividen diukur dengan skala rasio menggunakan dividend payout ratio, yaitu membandingkan dividen yang dibayarkan dengan laba yang tersedia bagi pemegang saham (Weygandt et al. 2013). Cash holdings adalah saldo kas yang ditahan terdiri dari kas dan setara kas yang diperlukan untuk memenuhi kebutuhan aktivitas operasional perusahaan. Pengukuran cash holdings diukur dengan skala rasio yang menggunakan log cash and cash equivalent (Nisasmara dan Musdholifah 2016, 126). Dewan Komisaris Independen diukur dengan skala rasio dan dirumuskan dengan membagi total dewan komisaris independen dengan total dewan komisaris (Nisasmara dan Musdholofah 2016).

\section{HASIL DAN PEMBAHASAN}

Statistik deskriptif memuat gambaran dari data yang dilihat dari nilai rata-rata, standar deviasi, serta nilai minimum dan maksimum. Berikut tabel 2 adalah hasil pengujian statistik deskriptif: 
Tabel 2 Hasil Uji Statistik Deskriptif

\begin{tabular}{lcccc}
\hline \multicolumn{1}{c}{ Variabel } & Minimum & Maksimum & Mean & $\begin{array}{c}\text { Std. } \\
\text { Deviation }\end{array}$ \\
\hline FIRM & 0,5375439 & 11,0873565 & 1,7747496 & 1,5427043 \\
MANAJERIAL & 0,0000002 & 0,40835914 & 0,3278924 & 0,0701071 \\
LEVERAGE & 0,1206347 & 0,83746229 & 0,4271628 & 0,1857845 \\
PROFIT & $-0,0032214$ & 0,33324523 & 0,0831162 & 0,0608407 \\
UKURAN & 24,899241 & 33,1340532 & 29,060541 & 1,7151783 \\
IOS & $-0,7513201$ & 0,33782824 & 0,0324916 & 0,0836603 \\
DIVIDEND & 0,0293670 & 1,80813143 & 0,3508644 & 0,2285059 \\
CASH & 9,8621802 & 13,4489689 & 11,0651756 & 0,8368969 \\
DKI & 0,1666700 & 0,75000000 & 0,3887631 & 0,0949087 \\
\hline
\end{tabular}

Hasil uji hipotesis adalah sebagai berikut:

Tabel 3 Hasil Uji Hipotesis

\begin{tabular}{lcc}
\hline \multicolumn{1}{c}{ Variabel } & B & Sig. \\
\hline MANAJERIAL & $-0,031$ & 0,594 \\
LEVERAGE & 0,160 & 0,011 \\
PROFIT & 0,719 & 0,000 \\
UKURAN & $-0,038$ & 0,764 \\
IOS & 0,013 & 0,810 \\
DIVIDEND & 0,257 & 0,000 \\
CASH & 0,077 & 0,530 \\
DKI & 0,024 & 0,656 \\
\hline
\end{tabular}

Kepemilikan manajerial memiliki nilai koefisien signifikansi sebesar 0,594 lebih besar sama dengan dari nilai alpha yaitu 0,05 . Dari hasil ini maka $\mathrm{H}_{1}$ tidak diterima, artinya kepemilikan manajerial tidak berpengaruh terhadap nilai perusahaan.

Financial leverage memiliki signifikansi sebesar 0,011 dan kurang dari nilai alpha yaitu 0,05 . Dari hasil ini maka $\mathrm{H}_{2}$ diterima, artinya financial leverage berpengaruh terhadap nilai perusahaan. Hasil pengujian tersebut juga menunjukkan bahwa terdapat standardized coefficients sebesar 0,160 atau financial leverage memiliki pengaruh positif terhadap nilai perusahaan yang berarti semakin besar nilai financial leverage maka akan semakin besar nilai perusahaan. Hal tersebut terjadi karena menjadi alat pengawasan untuk mengurangi masalah keagenan. Perusahaan dengan tingkat leverage yang tinggi dapat menunjukkan bahwa kesempatan perusahaan untuk bertumbuh juga semakin besar yang ditunjukkan dengan penggunaan hutang optimal yang dialokasikan pada proyek-proyek investasi yang menguntungkan dan akan membawa manfaat atau keuntungan bagi perusahaan serta investor di masa yang akan datang sehingga mampu meningkatkan nilai perusahaan dikemudian hari (Fanani dan Yan 2016). 
Profitabilitas memiliki nilai signifikansi sebesar 0,000 dan kurang dari nilai alpha yaitu 0,05 . Dari hasil ini maka $\mathrm{H}_{3}$ diterima, artinya profitabilitas berpengaruh terhadap nilai perusahaan. Hasil pengujian tersebut juga menunjukkan bahwa terdapat standardized coefficient sebesar 0,719 atau profitabilitas memiliki pengaruh positif terhadap nilai perusahaan yang berarti semakin besar profitabilitas perusahaan, maka akan semakin besar juga nilai perusahaan. Hal tersebut sesuai dengan teori sinyal yaitu ketika perusahaan dapat menghasilkan laba akan dianggap sebagai sinyal positif dan meningkatkan persepsi investor terhadap perusahaan sehingga nilai perusahaan akan meningkat.

Ukuran perusahaan memiliki nilai signifikansi sebesar 0,764 dan lebih besar sama dengan dari nilai alpha yaitu 0,05. Dari hasil ini maka $\mathrm{H}_{4}$ tidak dapat diterima, artinya ukuran perusahaan tidak berpengaruh terhadap nilai perusahaan.

Investment opportunity memiliki nilai signifikansi sebesar 0,810 dan lebih besar sama dengan dari nilai alpha yaitu 0,05 . Dari hasil ini maka $\mathrm{H}_{5}$ tidak dapat diterima, artinya investment opportunity tidak berpengaruh terhadap nilai perusahaan.

Kebijakan dividen memiliki nilai signifikansi sebesar 0,000 dan kurang dari nilai alpha yaitu 0,05 . Dari hasil ini maka $\mathrm{H}_{6}$ diterima, artinya kebijakan dividen berpengaruh terhadap nilai perusahaan. Hasil pengujian juga menunjukkan bahwa terdapat standardized coefficient sebesar 0,257 atau terdapat pengaruh positif kebijakan dividen terhadap nilai perusahaan yang berarti semakin tinggi kebijakan dividen maka akan semakin tinggi nilai perusahaan. Hal tersebut sesuai dengan teori sinyal, ketika perusahaan membagikan dividen secara berturut-turut maka investor akan mendapat sinyal bahwa perusahaan memiliki prospek menguntungkan di masa depan. Perusahaan yang dapat memberikan dividen tinggi juga akan mendapatkan nilai kepercayaan yang tinggi dari para investor, karena investor lebih menyukai kepastian tentang returns investasinya dan mengantisipasi risiko ketidakpastian tentang kebangkrutan perusahaan. Dividen yang tinggi akan membuat para investor tertarik sehingga meningkatkan permintaan saham. Permintaan saham yang tinggi akan membuat para investor menghargai nilai saham lebih besar dari pada nilai yang tercatat pada neraca perusahaan, sehingga nilai perusahaan juga tinggi.

Cash holdings memiliki nilai signifikansi sebesar 0,530 dan lebih besar sama dengan dari nilai alpha yaitu 0,05. Dari hasil ini maka $\mathrm{Ha}_{7}$ tidak dapat diterima, artinya cash holdings tidak berpengaruh terhadap nilai perusahaan.

Dewan komisaris independen memiliki nilai signifikansi sebesar 0,656 dan lebih besar sama dengan dari nilai alpha yaitu 0,05. Dari hasil ini maka $\mathrm{H}_{8}$ tidak dapat diterima, artinya dewan komisaris independen tidak berpengaruh terhadap nilai perusahaan.

Hasil analisis jalur dijelaskan pada gambar 1 berikut: 


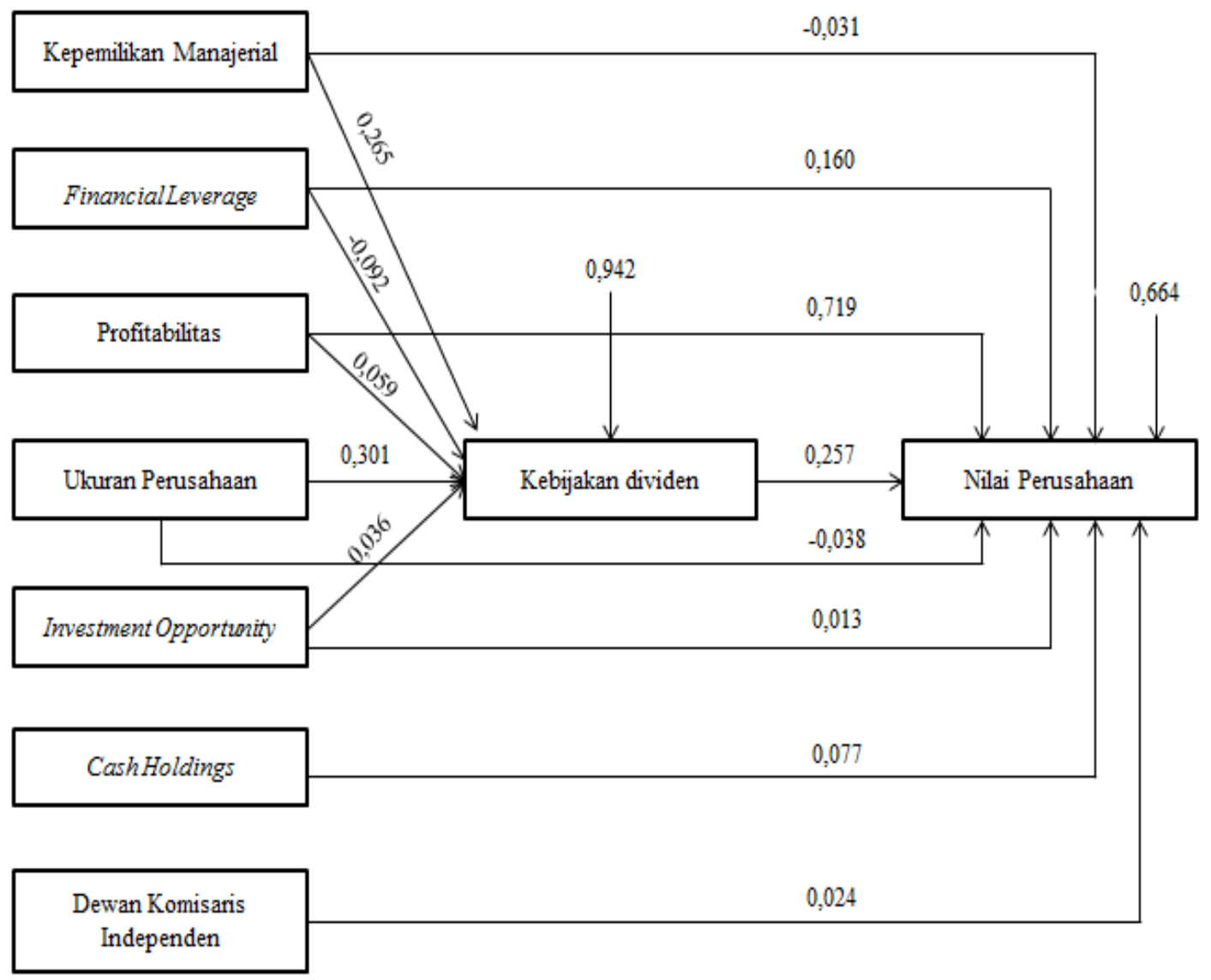

Pengaruh langsung kepemilikan manjerial terhadap nilai perusahaan (|-0,031|) lebih kecil dari pengaruh tidak langsung melalui kebijakan dividen $(0,265 \times 0,257=0,068)$, maka kebijakan dividen terbukti sebagai variabel intervening. Hasil tersebut menunjukkan bahwa $\mathrm{H}_{9}$ diterima, artinya kepemilikan manajerial berpengaruh terhadap nilai perusahaan melalui kebijakan dividen. Kepemilikan manajerial dapat menyatukan kepentingan pemegang saham dan manajer, maka dari itu manajer akan bertindak demi kemakmuran pemegang saham, salah satunya dengan membagikan dividen. Pembagian dividen dapat mempengaruhi persepsi investor dan meningkatkan nilai saham perusahaan sehingga dapat meningkatkan nilai perusahaan.

Pengaruh langsung financial leverage terhadap nilai perusahaan $(0,160)$ lebih besar dari pengaruh tidak langsung melalui kebijakan dividen $(-0,092 \times 0,257=|-0,023|)$, maka kebijakan dividen tidak terbukti sebagai variabel intervening. Hasil tersebut menunjukkan bahwa $\mathrm{H}_{10}$ tidak diterima, artinya financial leverage tidak berpengaruh terhadap nilai perusahaan melalui kebijakan dividen.

Pengaruh langsung profitabilitas terhadap nilai perusahaan $(0,719)$ lebih besar dari pengaruh tidak langsung melalui kebijakan dividen $(0,059 \times 0,257=0,015)$, maka kebijakan dividen tidak terbukti sebagai variabel intervening. Hasil tersebut menunjukkan bahwa $\mathrm{H}_{11}$ tidak diterima, artinya profitabilitas tidak berpengaruh terhadap nilai perusahaan melalui kebijakan dividen.

Pengaruh langsung ukuran perusahaan terhadap nilai perusahaan $(|-0,038|)$ lebih kecil dari pengaruh tidak langsung melalui kebijakan 
dividen $(0,301 \times 0,257=0,077)$, maka kebijakan dividen terbukti sebagai variabel intervening. Hasil tersebut menunjukkan bahwa $\mathrm{H}_{12}$ diterima, artinya ukuran perusahaan berpengaruh terhadap nilai perusahaan melalui kebijakan dividen. perusahaan besar akan cenderung membagikan dividen yang tinggi untuk menjaga reputasi di kalangan investor. Pembagian dividen yang konsisten ini dinilai sebagai sinyal positif bagi investor, karena investor lebih menyukai kepastian tentang returns investasinya dan mengantisipasi risiko ketidakpastian tentang kebangkrutan perusahaan.

Pengaruh langsung investment opportunity terhadap nilai perusahaan $(0,013)$ lebih besar dari pengaruh tidak langsung melalui kebijakan dividen $(0,036 \times 0,257=0,009)$, maka kebijakan dividen terbukti sebagai variabel intervening. Hasil tersebut menunjukkan bahwa $\mathrm{H}_{13}$ tidak diterima, artinya investment opportunity tidak berpengaruh terhadap nilai perusahaan melalui kebijakan dividen.

\section{PENUTUP}

Berdasarkan hasil penelitian dapat
diketahui bahwan financial leverage, profitabilitas, dan kebijakan dividen berpengaruh langsung terhadap nilai perusahaan sedangkan kepemilikan manajerial, ukuran perusahaan, investment opportunity, cash holdings, dan dewan komisaris independen tidak berpengaruh secara langsung. Hasil uji analisis jalur menunjukkan variabel kepemilikan manajerial dan ukuran perusahaan berpengaruh terhadap nilai perusahaan melalui kebijakan dividen.

Keterbatasan penelitian ini adalah Periode penelitian yang singkat, yaitu dari tahun 2014 sampai 2016, dimana periode ini tidak cukup untuk mewakili secara spesifik keadaan yang terjadi. Variabel yang digunakan hanya kepemilikan manajerial, financial leverage, profitabilitas, ukuran perusahaan, investment opportunity, kebijakan dividen, cash holdings, dan dewan komisaris independen.

Penelitian selanjutnya disarankan untuk menambahkan periode penelitian dengan jangka waktu yang lebih panjang sehingga dapat mewakili secara spesifik keadaan yang terjadi. Penelitian selanjutnya diharapkan menambahkan variabel independen yang tidak terdapat dalam penelitian ini seperti pertumbuhan penjualan, risiko perusahaan, dan komite audit.

\section{REFERENSI:}

Amah, Nik. 2012. Faktor-Faktor yang mempengaruhi Dividend Policy Perusahaan Go Public di Indonesia. Jurnal Akuntansi dan Pendidikan, 1(1), 45-55.

Arieska, Metha, dan Barbara Gunawan. 2011. Pengaruh Aliran Kas Bebas dan Keputusan Pendanaan Terhadap Nilai Pemegang Saham dengan Set Kesempatan Investasi dan Dividen Sebagai Variabel Moderasi. Jurnal Akuntansi dan Keuangan, 13(1), 13-23

Benson, B.W. dan Davidson III, W.N. 2009. Reexamining the managerial ownership effect on firm value. Journal of Corporate Finance, 15 (5), 573-586.

Dewi, Ayu Sri Mahatma dan Ary Wirajaya. 2013. Pengaruh Struktur Modal, Profitabilitas dan Ukuran Perusahaan pada Nilai Perusahaan. E-Jurnal Akuntansi Universitas Udayana, 4(2), 358-372.

Fanani, Zaenal dan Yan, Hendrick S. 2016. Struktur Kepemilikan dan Nilai Perusahaan. Journal of Islamic Economics and Business, 9 (1).

Godfrey, Jayne, Allan Hodgson, Ann Tarca, Jane Hamilton, and Scott Holmes. 2010. Accounting Theory. 7th Edition. Australia: John Wiley \& Sons Australia, Ltd. 
Ha, Nguyen Minh, dan Tai, Le Minh. 2017. Impact of Capital Structure and Cash Holdings on Firm Value: Case of Firms Listed on the Ho Chi Minh Stock Exchange. International Journal of Economics and Financial Issues, 7(1), 24-30.

Hasnawati, Sri dan Agnes Sawir. 2015. Keputusan Keuangan, Ukuran Perusahaan, Struktur Kepemilikan, dan Nilai Perusahaan Publik Indonesia. Jurnal Manajemen dan Kewirausahaan, 17(1), 65-75

Hermuningsih, Sri. 2013. Pengaruh Profitabilitas, Growth Opportunity, Struktur Modal Terhadap Nilai Perusahaan pada Perusahaan Publik di Indonesia. Buletin Ekonomi Moneter dan Perbankan, 16 (2), 128146.

Jensen, M and W. Meckling. 1976. Theory of the Firm: Managerial Behavior, Agency Cost and Ownership Structure, Journal of Finance Economic, 3, 305 - 360.

Juhandi, Nendi, Made Sudarma, Siti Aisjah, dan Rofiaty. 2013. The Effect of Internal factors and Stock Ownership Structure on Dividen Policy on Company's Value. International Journal of Business and Managemenet Invention. 2(11), 6-18.

Mawarni, Luh Fajarini Indah dan Ni Made Dwi Ratnadi. 2014. Pengaruh Kesempatan Investasi, Leverage, dan Likuiditas pada Kebijakan Dividen Perusahaan Manufaktur yang Terdaftar di BEl. E-Journal Akuntansi Universitas Udayana, 9 (3), 200-208.

Muryati, Ni Nyoman Tri Sariri dan I Made Sadha Suardikha. 2014. Pengaruh Corporate Governance pada Nilai Perusahaan. E-Jurnal Akuntansi Universitas Udayana, 9(2), 411-429.

Nisasmara, Prana Wahyu dan Musdholifah. 2016. Cash Holdings, GoodCorporate Governance, and Firm Value. Jurnal Dinamika Manajemen, 7(2),120- 131.

Nuringsih, Kartika. 2005. Analisis pengaruh Kebijakan Manajerial, Kebijakan Utang, ROA, dan Ukuran Perusahaan terhadap Kebijakan Dividen: Studi 1995-1996. Jurnal Akuntansi dan Keuangan Indonesia, 2 (2), 103-123.

Prasetia, Ta'dir Eko, Parengkuan Tommy, dan Ivone S. Saerang. 2014. Struktur Modal, Ukuran Perusahaan, dan Risiko Perusahaan Terhadap Nilai Perusahaan Otomotif yang Terdaftar di BEl. Jurnal Ekonomi, Manajemen,Bisnis, Akuntansi, 2(2), 879-889.

Rasyid, Abdul. 2015. Effects of Ownership Structure, Capital Structure, Profitability and Company Growth towards Firm Value. International Journal of Business and Management Invention, 4(4), 25-31.

Rizqia, Dwita Ayu, Siti Aisjah, dan Sumiati. 2013. Effect of Managerial Ownership, Financial Leverage, Profitability, Firm Size, and Investment Opportunity on Dividend Policy and Firm Value. Research Journal of Finance and Accounting, 4(11), 120-130.

Sekaran, Uma, dan Roger Bougie. 2016. Research Methods for Business, 6th Edition. United Kingdom: John Wiley \& Sons Ltd.

Setyowati, Tatik dan Nursiam. 2014. Pengaruh Profitabilitas, Kebijakan Dividen, dan Corporate Social Responsibility (CSR) Terhadap Nilai Perusahaan. Seminar Nasional dan Call for Paper Program Studi Akuntansi FEB UMS, 387-400.

Suharli, Michell. 2006. Studi Empiris Terhadap Faktor yang Mempengaruhi Nilai Perusahaan pada Perusahaan Go Public di Indonesia. Jurnal ManjemenAkuntansi, 6(1), 23-41.

Sukmono, Sigit. 2015. Effect of The Board of Commissioners of Its Value Through Quality of Financial Reporting. International Journal of Scientific \& Technology Research, 4(4), 197-205.

Sumanti, Jorenza Chiquita dan Marjam Mangantar. 2015. Analisis Kepemilikan Manajerial, Kebijakan Hutang dan Profitabilitas Terhadap Kebijakan Dividen dan Nilai Perusahaan Pada Perusahaan Manufaktur yang Terdaftar di BEl. Jurnal Ekonomi, Manajemen, Bisnis, dan Akuntansi. 3(1), 1141-1151.

Suroto. 2015. Pengaruh Keputusan Investasi, Keputusan Pendanaan dan Kebijakan Dividen Terhadap Nilai Perusahaan (Studi Empiris Pada Perusahaan LQ-45 yang Terdaftar di Bursa Efek Indonesia Periode Februari 2010- Januari 2015). Jurnal IImiah UNTAG Semarang, 4(3), 100-117.

Weygandt, Jerry J., Paul D. Kimmel, and Donald E. Kieso. 2013. Financial Accounting. IFRS Second edition. United States of America: John Wiley \& Sons, Inc.

Widodo, Putry Meilinda Rahayu. 2016. Pengaruh Keputusan Investasi, Pendanaan, dan Kebijakan Dividen terhadap Nilai Perusahaan. Jurnal IImu dan Riset Akuntansi, 5(1), 1-16. 
Widyasari, Nita Ayu, Suhadak, dan Achamd Husaini. 2015. Pengaruh Good Corporate Governance (GCG) dan Pengungkapan Corporate Social Responsibility (CSR) Terhadap Nilai Perusahaan. Jurnal Administrasi Bisnis, 26(1), 1-10.

Winarto, Jacinta. 2015. The Determinants of Manufacturer Firm Value in Indonesia Stock Exchange. International Journal of Information, Business and Management, 7(4), 323-349.

Yudiana, I Gede Yoga dan I Ketut Yadnyana. 2016. Pengaruh Kepemilikan Manajerial, Leverage, Investment Opportunity Set dan Profitabilitas pada Kebijakan Dividen Perusahaan Manufaktur. E-Jurnal Akuntansi Universitas Udayana, 15 (1), 112-141. 
